\title{
Development of Ready to Eat Fish Paste Using Chub Mackerel (Scomber japonicus)
} Tail Offcuts

\author{
H.M.M.C. Samarakoon ${ }^{1}$, P.P.S.K. Patabandi ${ }^{*}$, C.N. Walpita ${ }^{1}$, M.K.C. Priyadarshana ${ }^{1}$ and E. $^{2}$ \\ Udayathilake $^{2}$
}

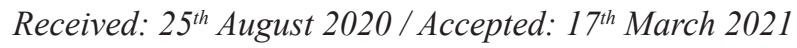

\begin{abstract}
Purpose: The Scomber japonicus (Chub mackerel) is one of the popular marine fish species used in canning industry yet the production of fish tail offcuts during canning process considered as a waste leaving the significant loss to the manufacturer. The present study was focused on the development of a ready to eat fish paste using chub mackerel tail offcuts.
\end{abstract}

Research Method: Fish paste was prepared using three (03) different recipes. Minced fish tail offcuts were incorporated at 63.5, 51.1 and $61.1 \%$ with spices and other ingredients added accordingly. To find the best recipe for chub mackerel, physicochemical properties, definite sensory attributes, stability and the safety of the fish pastes were examined.

Findings: Recipe 03 incorporated with $61.1 \%$ of minced fish had the highest overall acceptability together with maximum scores for flavour, colour and texture. Further, recipe 03 had the highest crude protein and lowest crude fat percentage. The $\mathrm{pH}$ of all fish pastes shown to have a significant reduction during the first 08 weeks nevertheless the values were within the acceptable level. Lowest free fatty acid content was also detected in recipe 03 while peroxide value was insignificant in all the recipes. Moreover, Clostridium botulinum was not detected in fish pastes which assured the safety of the end product during 08 weeks of storage at room temperature.

Research Limitation: The shelf life of the prepared fish pastes were not tested for a longer period.

Originality/Value: Chub mackerel tail offcuts can be successfully used to produce a ready to eat fish paste as a value-added fish product while minimizing the waste of edible by-products.

Keywords: Fish paste, Offcut, Scomber japonicas

\section{INTRODUCTION}

Seafoods including fish are highly perishable in nature and easily become unsuitable for human consumption and perhaps dangerous to health due to the number of reasons including microbial development, chemical alterations and breakdown by endogenous enzymes (Wang et al., 2017). Throughout the world, more than $27 \%$ of fish is lost or wasted between landing and consumption (Badonia et al., 1988). Therefore, post-harvest handling and transportation of fish require excessive care in order to maintain the quality and nutritional attributes (Huss et al.,
1998).

Fish canning is one of the processing methods of aquatic products which enables the extending shelf life thus making it less expensive during storage and other aspects of distribution

\footnotetext{
${ }^{I^{*} \text { Department of Livestock Production, Faculty of Agricultural }}$ Science, Sabaragamuwa University of Sri Lanka, Belihuloya, Sri Lanka.

saku@agri.sab.ac.lk

${ }^{2}$ Happy Cook Lanka Food (Pvt) Ltd, Ceylon Fisheries Corporation Building, Magalle, Galle

DORCID http://orcid.org/0000-0002-0922-7987
} 
(Myrseth, 1985). Fish canning process provides sterilization by applying sufficient heat to destroy microorganism and also prevents invading them into the end product (Sampels, 2015). However, there are some inherent problems in the canning process that may alter the stability and flesh disintegration which would affect the delicate flavour and texture of the end product. Besides, leach out of vitamins and proteins into cooking media are identified as the primary sources of loss of nutrients (Abraha et al., 2018).

In 2018, the global canned seafood market was estimated as USD 22.57 billion and it has been further increasing and projected to reach USD 29.14 billion in 2026. In addition to the durability as a ready to eat product, inexpensive nutritional properties of it have also been driving the market. Canned fish in Sri Lankan context is considered as one of the major imported fishery products that contributed about $38 \%(40,000 \mathrm{Mt})$ of the total share and $28 \%(9,500$ million LKR) of total import value in 2017. In order to minimize the reliance on importation, the ministry of fisheries facilitated the private sector to enter the canning fish industry. The first fish canning factory was established in Galle in year 2012 with the capital investment and daily production capacity of Rs. 840 million and 10,000 of cans, respectively. Subsequently, another company started a canned fish factory in Paliyagoda with the capital investment of Rs.170 Million and daily production capacity of 24,000 cans respectively (MFAR, 2015). With the development of the fish canning industry in Sri Lanka, 4.8 million cans were produced during the year 2017 (NARA, 2017).

However, in fish canning process, significant amount of offcuts have been produced and left unusable due to small size and the presence of bone particles. According to Arvanitoyannis and Kassaveti 2008, 1000 kilograms of filleting of de-headed white fish can produce up to 200-300 kilograms of offcuts and frames as solid waste. Hence, preparation of value-added products such as mince or mince-based products could be the best way of using these edible leftovers (Bae et al., 2007; Datta, 2013; Ghaly et al., 2013; Dhanapal et al., 2016).
Fish paste is one of the instant value-added canned products which is manufactured by using cooked fish mechanically broken down through various processing steps until it reaches the consistency of a paste (Montagne, 2003). Fish pastes represent a considerable portion of the protein intake of many people in Asia - Pacific region (FAO, 2015), especially by the poorest sections of the population. Besides, fish offcuts could be used for producing fish paste as a ready to eat fish product.

Chub mackerel is one of the migratory pelagic species which inhabit in both tropical and temperature areas including Indian, Atlantic and Pacific oceans. Chub mackerel carnivorous fish, primarily feed on small fish squids, copepods, and other crustaceans. It can reach up to $64 \mathrm{~cm}$ in body length (average length $=30 \mathrm{~cm}$ ) and a maximum weight of $2.9 \mathrm{~kg}$ (Hernández and Ortega, 2000).

As explained by Arvanitoyannis and Kassaveti (2008), the authors have also found that 9.5\% (95g out of $1 \mathrm{~kg}$ ) of chub mackerel (Scomber japonicus) tail offcuts were produced as leftovers. This tail offcuts were produced due to ununiform size since $70 \%$ of the fish coming to the processing factory do not have the standard size which is $250 \mathrm{~mm}$. This production of offcuts significantly affects the net profit of the company since they have estimated the loss is Rs 2,106,760.00 per month even after selling them for bakery purposes at a low price.

Therefore, the present study was aimed to develop thermally processed ready to eat fish paste using chub mackerel (Scomber japonicus) offcuts. Further, it aims to study the quality attributes including physicochemical and sensory properties, stability and the safety of the formulated fish pastes.

\section{MATERIALS AND METHODS}

Chub mackerel tail offcuts (average length = 3-4 cm) were used for the preparation of fish pastes. These tail offcuts were produced due to ununiformed fish which cannot be entirely used for the canning process. Spices and other 
ingredients used for the recipe development were collected from the local market in Galle, Sri Lanka. Polymer-coated tin-free steel (TFS) small cans (volume $=200 \mathrm{ml}$ ) were used as the containers and preparation was done in the fish can processing line with slight modifications.

\section{Recipe development}

Three (03) recipes were used for the preparation of fish paste, in which two recipes (recipe 01 and recipe 02 ) previously developed for Tilapia (Oreochromis mossambicus) (Dhanapal et al., 2016) and Pink Perch (Nemipterus japonicus) (Datta, 2013) were replaced with chub mackerel up to $63.50 \%$ and $51.10 \%$ respectively. Recipe 03 was primarily developed for chub mackerel during this study via conducting a series of preliminary trials. Spices used in recipe 03, were based on preferences of the local taste.

\section{The fish paste production process}

The tail offcuts were initially washed using the compartment sink to remove blood and dirt. After washing, offcuts were dipped in $20 \%$ brine solution for 5 minutes. Containers were filled with offcuts with water and precooked the content at $80^{\circ} \mathrm{C}$ to $90^{\circ} \mathrm{C}$ for 20 minutes. Subsequently, water was drained out and deboning was done manually. Spices and other ingredients were added and blended using the electrical blender. The mixture was filled into empty cans and sealed using seamer machine. Sealed cans were thoroughly washed and retorting was done at $121^{\circ} \mathrm{C}$ and pressure $0.9 \mathrm{~kg} / \mathrm{cm}^{2}$ for 55 minutes.

\section{End product evaluations}

During end product evaluations, three replicates $(\mathrm{r}=3)$ were used in each treatment (recipes/fish pastes) representing the same batch to avoid batch variations. An imported fish paste prepared using Yellowfin tuna (Thunnus albacares) taken from the market was used as the reference sample.

\section{Proximate analysis and colour determination}

General parameters such as moisture, dry matter (DM), ash, crude protein (CP) and crude fat (CF) were analyzed (AOAC, 1995). The colour properties such as lightness $\left(1^{*}\right)$, redness $\left(a^{*}\right)$, and yellowness $\left(b^{*}\right)$ were measured using Chroma meter CR-400 Konica Minolta (Tharaka et al., 2016). All the measurements were taken on wet basis (\% wet basis).

\section{Determination of sensory attributes}

Sensory attributes i.e. colour, texture, flavour, odour, spreadability and overall acceptability were tested using untrained panellist $(n=30)$ at the age between 21-55 and data were analyzed using a 9-point hedonic scale.

Table 01: Different ingredients (\%) used for the development of the recipes

\begin{tabular}{cccc}
\hline Ingredients (\%) & Recipe 01 & Recipe 02 & Recipe 03* \\
\hline Fish mince (Chub mackerel) & 63.50 & 51.10 & 61.08 \\
Sunflower oil & 11.50 & - & - \\
Coconut oil & - & 24.00 & 14.10 \\
Butter & - & 10.40 & - \\
Water & 9.25 & - & 17.30 \\
Salt & 1.80 & 1.46 & 0.91 \\
Corn flour & - & - & 2.44 \\
Spices and other ingredients & 13.95 & 13.04 & 4.17 \\
\hline Total & 100.00 & 100.00 & 100.00 \\
\hline
\end{tabular}

*As the recipe developed here is to be patented, exact proportions of the ingredients are not disclosed here. 


\section{Determination of shelf-life}

\section{Determination of $\mathrm{pH}$}

Homogenized solution was prepared for $\mathrm{pH}$ determination by mixing fish paste $(5 \mathrm{~g})$ with $45 \mathrm{ml}$ of distilled water (Kolade 2015). pH was measured using a $\mathrm{pH}$ meter (HQ 40d) at 7-day intervals during the storage period of 8 weeks at ambient temperature.

\section{Determination of rancidity}

Hydrolytic rancidity and oxidative rancidity were determined via measuring free fatty acid (FFA) and peroxide values (PV) respectively (AOCS, 1998). A required fat for the experiment was obtained via Soxhlet extraction.

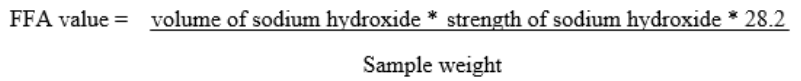

Sample weight

Where, $\mathrm{S}=$ titrated value of sample, $\mathrm{B}=$ titrated value of blank, $\mathrm{N}=$ normality

\section{Microbial evaluation - Detection of Clostridium botulinum}

Microbiological test for the detection of $C$. botulinum was conducted after 08 weeks storage period at ambient temperature to assure the safety of the final product at Medical Research Institute (MRI), Colombo, Sri Lanka.

\section{Statistical Analysis}

Data analysis was done using SAS 9.0 version. One-way ANOVA was used to compare means of proximate analysis and colour determination. Sensory data was analyzed using the Friedman test of Minitab 16 software. Two-way ANOVA was conducted to determine the $\mathrm{pH}$, FFA and PV. Duncan's multiple range test was used to determine the differences between treatment means. Graphical illustrations were done using Microsoft Excel 2010.

\section{RESULTS AND DISCUSSION}

\section{Proximate analysis}

\section{Moisture content}

As shown in Figure 01, the highest moisture content was detected in the reference sample $(65.24 \%)$ whereas the lowest was in recipe 02 $(59.78 \%)$. However, the moisture content was not significant $(p>0.05)$ amongst the tested recipes. The highest moisture content in the reference sample was probably due to the addition of white wine vinegar and water respectively. During the preparation, the high percentage of water $(17.3 \%)$ was added to the recipe 03 could be the reason for its high moisture content compared to the other recipes. Ha et al. (2001) reported that moisture content affects the hardness of the fish paste. According to Adawyah (2008), fish paste can contain moisture around $35-50 \%$, if the paste is prepared only pounded with salt. Water content in fish paste often determines its nutritive value and taste. Hence, a significant loss of moisture under the drying condition (Precooking stage; 80-90 ${ }^{\circ} \mathrm{C}$ ) caused to loss of volatile substances, which contained in fish and also those produced during the thermal process (Anggo et al., 2015). Even the precooking process can lead to a reduction of moisture in mackerel fish (Sreenath, 2007). It is suggested that adding water as an ingredient would help to retain the optimum water content in the final product. Further, stability and shelf life of the end product also depend on the water activity for instance, it is vital for microbial growth and autolysis (Isengard, 2001).

\section{Ash content}

Ash content refers to the remaining inorganic residue after being ignited or oxidized of organic matter in a given food sample. It is also an important attribute for determining the quality of food ingredients (Ismail, 2017). Ash content generally represents the mineral of the prepared fish pastes. According to Figure 02, reference sample showed the lowest ash content $(1.58 \%)$ $(p<0.05)$. Ash content of chub mackerel fish muscles was found to be $1.50 \%$ (Lall, 1995) and a minimum of $1 \%$ in salted chub mackerel fish 
products (Doe, 1998). According to (Lall, 1995), processed fishery product has a higher value of sodium content than raw muscle due to adding salt during processing. Therefore, high mineral content in developed fish pastes could be due to addition of salt and particularly in recipe 02 $(2.98 \%)(p<0.05)$ due to incorporation of butter (10.4\%) which contains $2 \%$ of salt.

\section{Crude protein content}

There was no significant difference $(p>0.05)$ observed in crude protein content (CP) between the treatments (see. Figure 03). The lowest CP content $(p<0.05)$ was found in the reference sample $(12 \%)$ and could be due to addition of filler agents nevertheless the highest CP

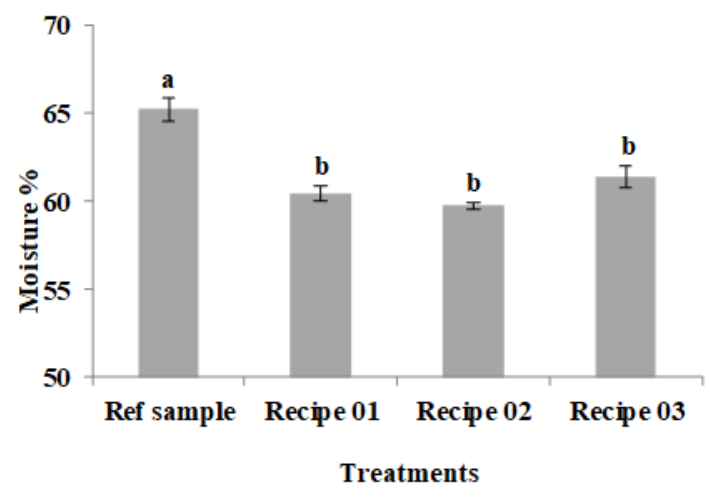

Results are expressed as mean \pm standard error of three replicates and error bars with alphabet letters designate significant difference $(p<0.05)$.

Figure 01: Moisture content of Recipe 01, 02, 03 and Reference sample. percentage was in recipe 03 (16.89\%). According to the Oyelese (2007) and Moon et al. (2009), chub mackerel muscle contains $18-19 \%$ protein ( $\%$ wet basis) yet, it can depend on many factors including the stage of growth, season, sex etc. (Celik, 2008; Shim et al., 2017). The protein content (dry basis\%) in fish paste ranged from 47.78 to $57.55 \%$ for Salmon paste, $49.12 \%$ to $56.07 \%$ for Herring paste and $42.66 \%$ to $53.32 \%$ for Anchovy paste (Khater and Farag, 2016). Although several studies recorded approximate protein percent in various fish products (Naila et al., 2011; Adeyeye et al., 2016). The low protein content of the fish products could be attributed to the processing conditions and the time of fish harvest (Kristinsson and Rasco, 2000; Rezaei and Hedayatifard, 2013).

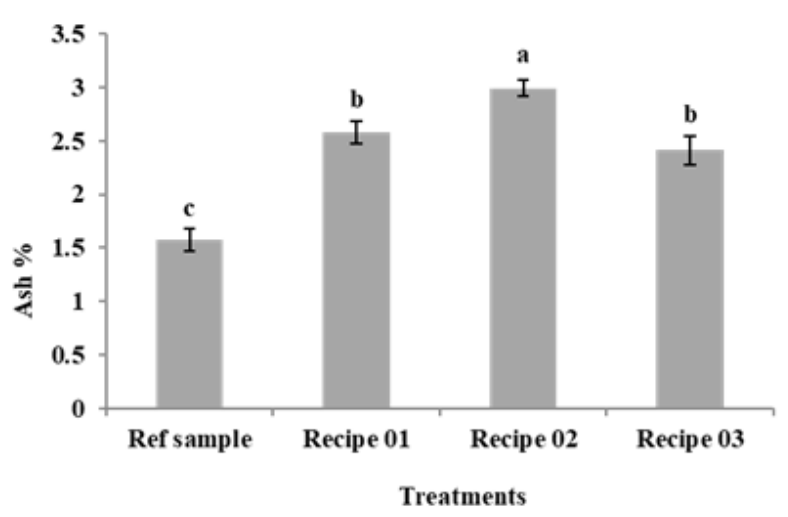

Results are expressed as mean \pm standard error of three replicates and error bars with alphabet letters designate significant difference $(p<0.05)$.

Figure 02: $\quad$ Ash content of Recipe 01, 02, 03 and Reference sample.

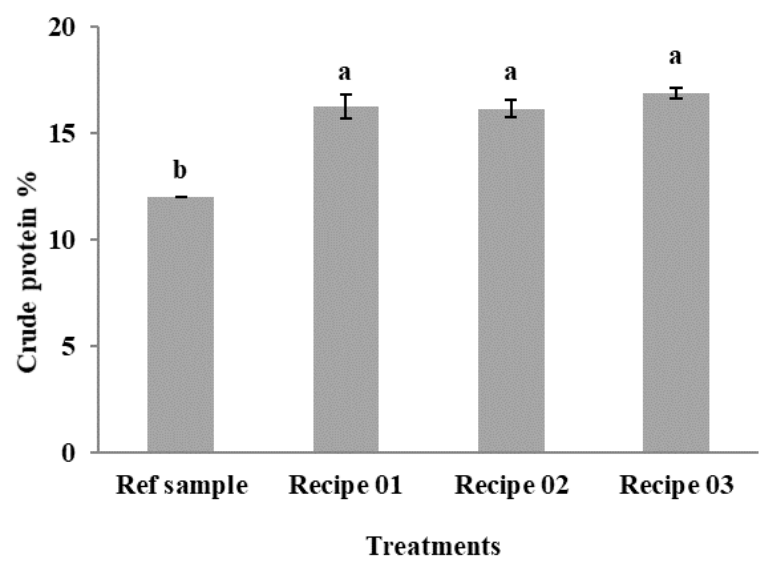

Results are expressed as mean \pm standard error of three replicates and error bars with alphabet letters designate significant difference $(p<0.05)$.

Figure 03: $\quad$ Crude protein (CP) content of Recipe 01, 02, 03 and Reference sample. 


\section{Crude fat content}

As shown in Figure 04, significant difference $(p<0.05)$ was observed in crude fat content among reference sample, recipe 01 and 03 respectively. The highest crude fat $(20.6 \%)$ was observed in the reference sample whereas the lowest $(17.10 \%)$ observed in recipe 03. According to (Dhanapal et al., 2016), fat content in Tilapia fish paste was $13.35 \pm 0.04 \%$ however, using the same recipe (recipe 01) for chub mackerel gave the highfat percentage $(17.18 \%)$ due to high crude fat content $(18.62 \%)$ in cub mackerel fish muscles (Bae and Lim, 2011). Moreover, high-fat content in the recipe 02 might be due to the addition of butter and coconut oil.

Thermal treatment during the canning process has a great impact on oxidizing nutrients including vitamins and lipids. Moreover, heating is also responsible for leaching out of water-soluble nutrients i.e. proteins, minerals and vitamins. This could be further increased if the canning is carried out in oily media since, denatured proteins due to the heating process could release a considerable amount of water into the can headspace (Roe et al., 2013).

\section{Colour Determination}

The colour values of the end products were measured using three criteria i.e. lightness, redness and yellowness. There was a significant difference $(p<0.05)$ observed in the lightness

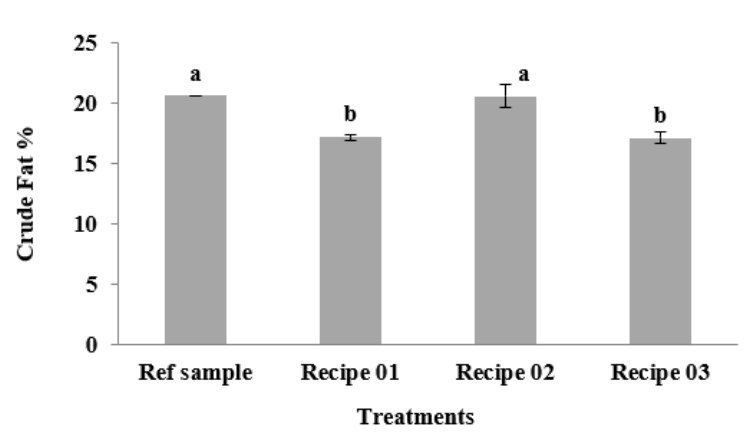

Results are expressed as mean \pm standard error of three replicates and error bars with alphabet letters designate significant difference $(p<0.05)$.

Figure 04: Crude fat (CF) content of Recipe $01,02,03$ and Reference sample. value between recipe 03 and other treatments. However, the highest lightness value (60.19 $\pm 0.07)$ was expressed in a reference sample prepared using Yellowfin tuna.

High lightness value in all treatments due to leaching of white connective tissue contains collagen located between muscle segments. Precooking process caused to increase in lightness value of mackerel meat besides, incorporation of other ingredients in bread-spread fish paste particularly the addition of chili powder (Tharaka et al., 2016). The highest redness value (12.30 \pm 0.2 ) was detected in reference sample whereas the lowest value $(4.65 \pm 0.32)$ was found in recipe 01 claiming the redness value of chub mackerel fish muscles higher than the white muscle (Tharaka et al., 2016). Highest yellowness value $(22.80 \pm 0.50)$ was detected in recipe 02 while the lowest $(p<0.05)$ in recipe $03(19.12 \pm 0.78)$.

\section{Evaluations of sensory attributes}

To determine the best recipe for chub mackerel fish paste, a sensory evaluation was conducted. Following sensory attributes i.e. colour, texture, spreadability, odour and the overall acceptance were measured. A fish paste available in the market was used as the reference sample. Sensory evaluation is an important method for valuation of freshness and quality attributes in fish processing. A product cannot be marketed unless sensory analysis results are acceptable (Uzunlu and Yildirim, 2003).

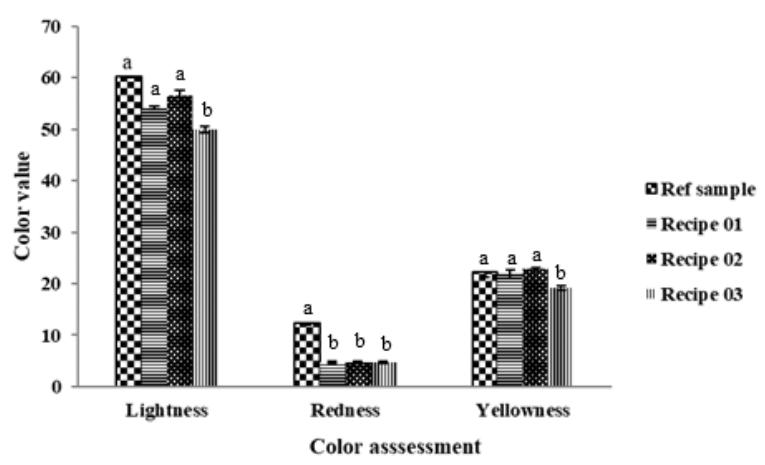

Results are expressed as mean \pm standard error of three replicates and error bars with alphabet letters designate significant difference $(p<0.05)$.

Figure 05: Lightness, redness and yellowness of developed fish pastes. 


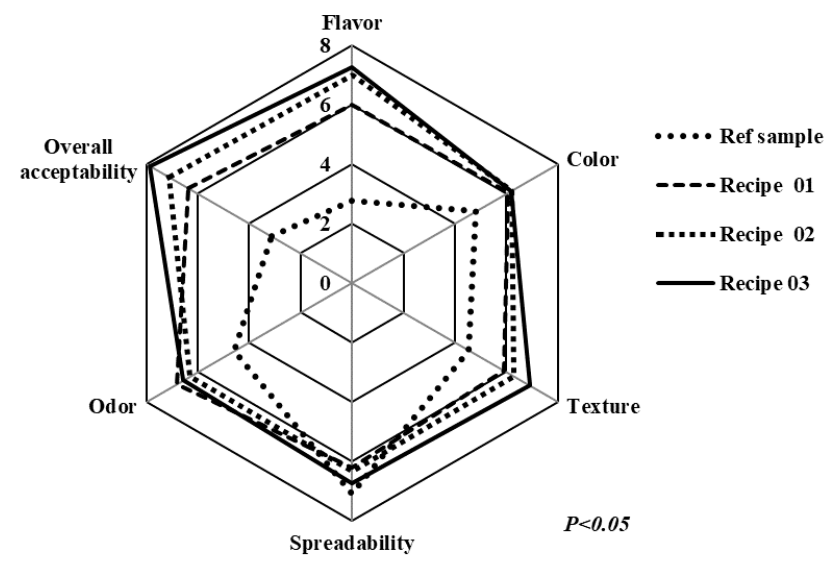

Figure 06: Sensory attributes with the attained values of the Recipe 01, 02, 03 and Reference sample

As a result of high temperature, heat-sensitive nutrients can be altered thus; nutritional and sensory attributes could be demoted due to formation of undesirable compounds (Aberoumand, 2014; Mesías et al., 2015). All the tested sensory attributes showed significant $(p<0.05)$ differences among treatments. As shown in the Figure 06, recipe 03 was ranked as the best but for spreadability. In contrast, lowest scores were obtained by the reference sample. Some of the ingredients used in the preparation of the reference sample such as mayonnaise, xanthan gum, egg yolk and sunflower oil could be the reason for its maximum spreadability. Overall acceptability of the product signifies the market potential. Hence, recipe 03 seemed the best compared with others. However, concerning its spreadability which is considered as one of the main attributes in the final product, it needs to be improved. The flavouring agents such as black pepper and garcinia used for recipe 03 might be the reason for its highest acceptability as described by Nair (2011) and Massullo et al. (2008) respectively.

\section{Determination of shelf life}

It was reported that the ingredients used, microbiological load, hygienic conditions and formation of undesirable products during processing affected the shelf life of fish product (Kaba et al., 2012; Aberoumand, 2014).

\section{Determination of $\mathrm{pH}$}

The $\mathrm{pH}$ test is one of the methods used to determine the deterioration of the fish muscle. According to Figure 07, all the fish pastes expressed the rapid declining of $\mathrm{pH}$ during the first 4 weeks. However, from 5 weeks onwards the rate of declining $\mathrm{pH}$ was decreased and finally stabilized. According to Anggo et al. (2015), $\mathrm{pH}$ determines the fermentation process carried out by the various microorganisms. Throughout the fermentation process $\mathrm{pH}$ increases however, it tends to decline at the end (Adawya, 2008). Further, research result of Zeng et al. (2014), reported that $\mathrm{pH}$ value declined lower than 4.5 due to high acidifying nature of Chinese traditional fermented whole fish product which contained less amount of salt. The $\mathrm{pH}$ decline of the fish paste can also be due to lactic acid formation which could probably occur a result of lipolytic rancidity in butter and promotes lipid oxidation with increasing storage time (Huss, 1995). Added ingredients such as lemon and garcinia can also be the reason for $\mathrm{pH}$ reduction due to the acidic nature of those ingredients. Further, these generated results are compatible with the previous studies conducted for Tilapia fish paste by Dhanapal et al. (2016) and Illangakoon et al. (2015) respectively. 


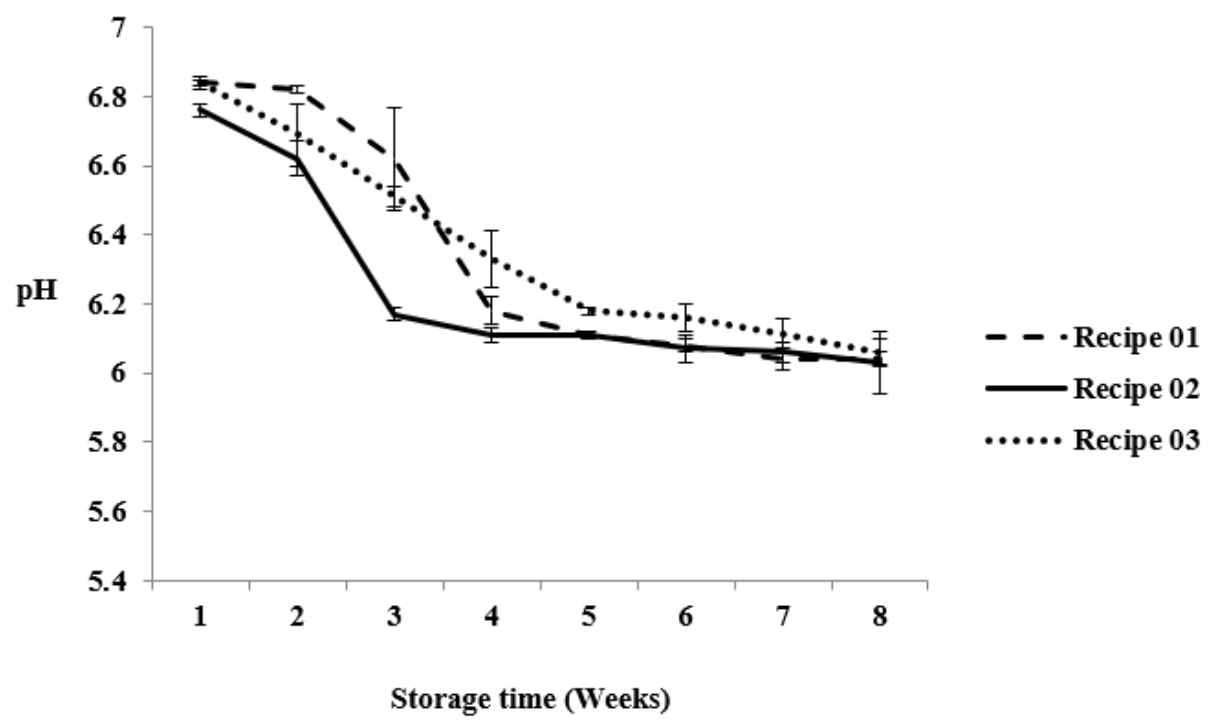

Figure 07: Changes of mean pH values of chub mackerel fish pastes during 8 week of storage at ambient temperature.

\section{Determination of Hydrolytic Rancidity -Free Fatty Acid (FFA) value}

According to the international association of fish meal and oil manufactures permissible limit of FFA value of crude fish oil was 1-7\% (Bako, 2017). As shown in Table 02, recipe 03 had the lowest FFA value at day $60(3.57 \pm 0.33)$ whereas recipe 02 had the highest $(4.88 \pm 0.32)$. Hence all the developed fish paste is within the allowable limit of FFA. High FFA value in recipe 02 might be due to incorporation of ingredients rich in fats such as coconut oil (24\%) and butter (10.4\%). Free fatty acids accumulation during storage and processing has a great impact on the quality of the final products including the shelf life (Koning and Mol, 1991). The presence of FFA primarily affects for the textural modifications of the product via association with proteins. It is thought to be the effect of FFA on myofibrillar proteins yet the mechanism behind this process has not been revealed (Bernárdez et al., 2005).

\section{Determination of Oxidative Rancidity - Peroxide Value (PV)}

According to the codex general standard (1999), acceptable peroxide value for fat and oils is up to 10 mill equivalents of active oxygen $/ \mathrm{kg}$. There was no countable PV detected in all the treatments during the storage period. Hence, fish pastes produced in this study were free from the oxidative rancidity for the period of 60 days. Cooking process during canning prevents lipid oxidation and further interaction of oxidize lipids with protein like other constituents due to inactivation of endogenous enzymes (Naik et al., 2014). According to the Naik et al. (2014), adding brine solution also increased the peroxide value during storage contrasting the results obtained in this study. This difference might be due to addition of spices such as Curry leaves (Murraya koenigii) (Jain et al., 2012), Cumin seed (Cuminum cyminum) (Rebey et al., 2012) and Black pepper (Piper nigrum) which have antioxidant properties that lead to scavenging of free radicals (Gülçin, 2005).

\section{Microbial analysis (Detection of Clostridium botulinum)}

Clostridium botulinum is an anaerobic, heat resistant, spore-forming bacterium responsible for producing botulinum toxins under lowoxygen conditions (Brown, 2000). According to the USDA (2013), the canned product should be free from $C$. botulinum. According to the results, all the tested recipes were negative for Clostridium botulinum during 60 days of storage period claiming that these fish pastes are safe for human consumption for the 60 days of storage period. 
Table 02: $\quad$ Changes of free fatty acid values (FFA) of the fish paste during 60 days of storage time.

\begin{tabular}{ccc}
\hline Recipe & Day 1 & Day 60 \\
\hline Recipe 01 & $2.80 \pm 0.56^{\mathrm{bA}}$ & $3.76 \pm 0.33^{\mathrm{bA}}$ \\
Recipe 02 & $3.93 \pm 0.53^{\mathrm{aA}}$ & $4.88 \pm 0.32^{\mathrm{aA}}$ \\
Recipe 03 & $2.63 \pm 0.33^{\mathrm{bB}}$ & $3.57 \pm 0.33^{\mathrm{bA}}$ \\
\hline
\end{tabular}

Mean FFA values of the particular recipes are given in the table. Different letters in the same column show the treatment effect whereas letters in the same row shows the effect of storage period.

\section{CONCLUSION}

Chub Mackerel (Scomber japonicus) tail offcuts can be effectively utilized as a raw material to during this study had the highest overall produce a fish paste. Further, recipe 03 developed acceptability in terms of sensory attributes, nutritional value and shelf life.

\section{REFERENCES}

Aberoumand, A. (2014). Studies on the effects of processing on food quantity of two selected consumed marine fishes in Iran. International Food Research Journal, 21(4), 1429.

Abraha, B., Admassu, H., Mahmud, A., Tsighe, N., Shui, X.W. and Fang, Y. (2018). Effect of processing methods on nutritional and physico-chemical composition of fish: a review. Food Processing and Technology, 6(4), pp.376-382. DOI: 10.15406/mojfpt.2018.06.00191

Adawyah, R. (2008). Processing and Preservation of fish. PT Bumi Aksara. Jakarta.

Adeyeye, S. A., Oyewole, O. B., Obadina, A. O., Omemu, A. M., Adeniran, O. E. and Oyedele, H. A. (2016). Assessment of quality and safety of traditional smoked spotted tilapia fish (Tilapia mariae) from Lagos State, Nigeria. Nutrition and Food Science. DOI: 10.1108/NFS-05-20150059

Alimentarius, C. (1999). Codex standard for named vegetable oils. Codex stan, 210, 1-13.

Arvanitoyannis, I. S., \& Kassaveti, A. (2008). Fish industry waste: treatments, environmental impacts, current and potential uses. International journal of food science \& technology, 43(4), 726-745. doi:10.1111/j.1365-2621.2006.01513.x

Anggo, A. D., Ma'ruf, W. F., Swastawati, F. and Rianingsih, L. (2015). Changes of amino and fatty acids in anchovy (Stolephorus Sp) fermented fish paste with different fermentation periods. Procedia Environmental Sciences, 23(1), 58-63. DOI: 10.1016/j.proenv.2015.01.009

AOAC. (1995). Official Methods of Analysis. USA: The Association of Official Analytical Chemists.

AOCS. (1998). Official Methods and Recommended Practices of the American Oil Chemists'Society. $5^{\text {th }}$ edn, Firestone D (Ed.), AOCS Press, Champaign, Methods Cc 13b-45, Ce 2-66.

Arvanitoyannis, I. S. and Kassaveti, A. (2008). Fish industry waste: treatments, environmental impacts, current and potential uses. International journal of food science \& technology, 43(4), 726-745. DOI:10.1111/j.1365-2621.2006.01513.x 
Badonia, R., Ramachandran, A. and Sankar, T. V. (1988). Quality problems in fish processing. Journal of the Indian Fisheries Association, 18, 283-287.

Bae, J. H., Yoon, S. H. and Lim, S. Y. (2011). Heavy metal contents and chemical compositions of Atlantic (Scomber scombrus), Blue (Scomber australasicus), and Chub (Scomber japonicus) Mackerel muscles. Food Science and Biotechnology, 20(3), 709-714. DOI: https://doi. org/10.1007/s10068-011-0100-z

Bae, M. S., Ha, J. U. and Lee, S. C. (2007). Quality properties of high calcium fish paste containing anchovy. Korean journal of food and cookery science, 23(4), 561-566. DOI: http://dx.doi. org/10.7318/KJFC/2013.28.6.657

Bako, T., Victor, U. I., \& Awulu, O. (2017). Criteria for the extraction of fish oil. Agricultural Engineering International: CIGR Journal, 19(3), 120-132.

Bernárdez, M., Pastoriza, L., Sampedro, G., Herrera, J. J. and Cabo, M. L. (2005). Modified method for the analysis of free fatty acids in fish. Journal of agricultural and food chemistry, 53(6), 1903-1906. DOI: https://doi.org/10.1021/jf040282c

Boz, Z., Uyar, R. and Erdoğdu, F. (2014). Heat treatment of foods Principles of Canning.

Brown, K.L. (2000). Control of bacterial spores. British Medical Bulletin, 56(1), 158-171

Celik, M. (2008). Seasonal changes in the proximate chemical compositions and fatty acids of chub mackerel (Scomber japonicus) and horse mackerel (Trachurus trachurus) from the north eastern Mediterranean Sea. International journal of food science \& technology, 43(5), 933-938. https:// doi.org/10.1111/j.1365-2621.2007.01549.x

Datta, S. (2013). Rigor mortis and fish spoilage. Manual on Fish Processing and Value Added Fish Products. Mahapatra, BK, Pailan, GH, Datta, S., Sardar, P., and Munilkumar, S. (Eds.). India: Director, Central Institute of Fisheries Education Mumbai, 27-38.

Dhanapal, K., Basu, S., Venkateshwarlu, G., Nayak, B.B. and Reddy, G.V.S. (2016). Development of ready to serve tilapia sandwich paste in retortable pouches. International Journal of Science, 5(02) pp. $457-474$.

Doe, P. E. (Ed.). (1998). Fish drying and smoking: Production and quality. CRC Press.

Food and Agriculture Organization of the United Nations (FAO). (2015). Fisheries and Aquaculture Department Fishery statistical collection. Fisheries commodities and trade. From http:/www. fao.org/fishery/ Fishery statistics/global commodities production/en.

Food and Agriculture Organization of the United Nations (FAO). (2018). Fish projections in the OECD-FAO Agricultural Outlook 2017-2026 | globefish | Food and Agriculture Organization of the United Nations. From http://www.fao.org/in-action/globefish/news-events/details-news/ en/c/1032635.

Ghaly, A. E., Ramakrishnan, V. V., Brooks, M. S., Budge, S. M. and Dave, D. (2013). Fish Processing Wastes as a Potential Source of Proteins. Amino acids and oils: a critical review. J Microb Biochem Technol, 5(4), 107-129. DOI: http://dx.doi.org/10.4172/1948-5948.1000110

Ghaly, A.E., Dave, D., Budge, S. and Brooks, M.S. (2010). Fish spoilage mechanisms and preservation techniques. American Journal of Applied Sciences, 7(7), p.859. DOI: 10.3844/ AJASSP.2010.859.877 
Gülçin, İ. (2005). The antioxidant and radical scavenging activities of black pepper (Piper nigrum) seeds. International journal of food sciences and nutrition, 56(7), pp.491-499. DOI: 10.1080/09637480500450248

Ha, J. U., Koo, S. G., Lee, H. Y., Hwang, Y. M., \& Lee, S. C. (2001). Physical properties of fish paste containing Agaricus bisporus. Korean Journal of Food Science and Technology,33(4),451-454.

https://www.verifiedmarketresearch.com/product/canned-seafood-market/

Hernández, J. J. C., \& Ortega, A. T. S. (2000). Synopsis of biological data on the chub mackerel (Scomber japonicus) Houttuyn, 1782) (No. 157). Food \& Agriculture Org..

Huss, H. H. (Ed.). (1995). Quality and quality changes in fresh fish (Vol. 348). Rome: FAO.

Huss, H. H., Boerresen, T., Dalgaard, P., Gram, L., \& Jensen, B. (1998). Quality and quality changes in fresh fish. FAO, Documento Tecnico de Pesca (FAO).

Illangakoon, I.M.I.V. and Abeyrathne, E.D.N.S. (2015). Development of a Fish Paste with Oreochromis mossambicus and Coccina grandis as a Natural Blood Glucose Reduction Food. IICBEE, Penang, Malaysia, pp.5-10. DOI: http://dx.doi.org/10.15242/IICBE.C0215114

Isengard, H.D. (2001). Water content, one of the most important properties of food. Food Control. 12: 395 - 400. https://doi.org/10.1016/S0956-7135(01)00043-3

Ismail, B. P. (2017). Ash content determination. In Food Analysis Laboratory Manual (pp. 117-119). Springer, Cham. DOI: https://doi.org/10.1007/978-3-319-44127-6_11

Jain, V., Momin, M. and Laddha, K. (2012). Murraya koenigii: An updated review. International Journal of Ayurvedic and Herbal Medicine, 2(04), pp.607-627.

Kaba, N., Özer, Ö., \& Corapc1, B. (2012). The determination of some quality parameters of smoked gar fish meat balls. Journal of Fisheries Sciences. com, 6(4), 357-367.

Khater, D. F. and Farag, S. E. S. (2016). Evaluation of bacterial and chemical quality of new manufactured pasted fish products in a large scale fish processing plant, Egypt. Benha Veterinary Medical Journal, 31(2), 63-72. DOI: 10.21608/BVMJ.2016.31263

Kolade, O.Y. (2015). Short communication evaluation of quality loss in a fish based, ready-to-eat food (fish roll) during refrigerated storage. doi:10.5707/cjapplsci.2015.10.1.11.17

Koning, A. J. and Mol, T. H. (1991). Quantitative quality tests for frozen fish: Soluble protein and free fatty acid content as quality criteria for hake (Merluccius capensis) stored at $-18 \mathrm{C}$. Journal of the Science of Food and Agriculture, 54(3), 449-458. DOI: https://doi.org/10.1002/ jsfa. 2740540316

Kristinsson, H. G. and Rasco, B. A. (2000). Fish protein hydrolysates: production, biochemical, and functional properties. Critical reviews in food science and nutrition, 40(1), 43-81. DOI: $10.1080 / 10408690091189266$

Lall, S.P. (1995). Macro and trace elements in fish and shellfish. Fish and fishery products: composition, nutritive properties and stability, pp.187-214. 
Masullo, M., Bassarello, C., Suzuki, H., Pizza, C. and Piacente, S. (2008). Polyisoprenylated benzophenones and an unusual polyisoprenylated tetracyclic xanthone from the fruits of Garcinia cambogia. Journal of Agricultural and Food chemistry, 56(13), pp.5205-5210. DOI: https://doi.org/10.1021/jf800416j

Mesías, M., Holgado, F., Sevenich, R., Briand, J. C., Márquez Ruiz, G., \& Morales, F. J. (2015). Fatty acids profile in canned tuna and sardine after retort sterilization and high pressure thermal sterilization treatment.

Ministry of Fisheries and Aquatic Resources Development (MFDA). (2016). Fisheries Statistics 2015.

Moon, S. K., Hong, S. N., Kim, I. S. and Jeong, B. Y. (2009). Comparative analysis of proximate compositions and lipid component in cultured and wild mackerel Scomber japonicus muscles. Korean Journal of Fisheries and Aquatic Sciences, 42(5), 411-416.

Montagne, P. (2003). The concise Larousse gastronomique: the world's greatest cookery encyclopedia. Hamlyn Publishing Group.

Myrseth, A. (1985). Planning and engineering data. Fish canning. FAO Fisheries Circular (FAO).

Naik, J., Raju, C. and Manjuntha, A. (2014). Studies on the quality of canned fishery products prepard using ice stored mackerel and pink perch. Indian Journal of Science Research and Technology, 2, pp.71-78.

Naila, A., Flint, S., Fletcher, G. C., Bremer, P. J. and Meerdink, G. (2011). Chemistry and microbiology of traditional Rihaakuru (fish paste) from the Maldives. International Journal of Food Sciences and Nutrition, 62(2), 139-147. DOI: 10.3109/09637486.2010.515566

Nair, K. P. (2011). Agronomy and Economy of Black Pepper and Cardamom: The" King" and" Queen" of Spices. Elsevier.

National Aquatic Resources Research and Development Agency (NARA). (2015). Fisheries Outlook 2015.

Oyelese, O. A. (2007). Hypoxanthine Levels, Chemical Studies and Bacteria Flora/Count of Frozen/Thawed Market Simulated Chub Mackerel (Scomber japonicus) under Cold Storage Temperature Conditions. Research Journal of Applied Sciences, 2(3), pp.295-300.

Pagarkar, A.U., Joshi, V.R., Baug, T.E. and Kedar, J.G. (2011). Value addition is need of seafood industries. Fish Coops, 23(4), pp.8-14.

Pandey, G., Raju C.V., Jagpal and Prasad, H. (2018). Changes in the proximate composition of pink perch during super chilling in solar operated refrigerated fish vending unit and its importance in human health. Pandey Journal of Pharmacognosy and Phytochemistry, 7(1), pp. 941-945. Pp.187-213, CAB International, Walling ford, UK.Products: Composition, Nutritive Properties and Stability (Ruiter, A., Ed.)

Rebey, I.B., Jabri-Karoui, I., Hamrouni-Sellami, I., Bourgou, S., Limam, F. and Marzouk, B. (2012). Effect of drought on the biochemical composition and antioxidant activities of cumin (Cuminum cyminum L.) seeds. Industrial Crops and Products, 36(1), pp.238-245. DOI: doi:10.1016/j. indcrop.2011.09.013

Rezaei, N. and Hedayatifard, M. (2013). Evaluation of qualitative changes of fish fingers made from big head carp (Aristichthys nobilis) during frozen storage. International Journal of AgriScience, 3(10), 796-806. 
Roe, M., Church, S., Pinchen, H. and Finglas, P. (2013). Nutrient analysis of fish and fish products: Sampling Report. Institute of Food Research.

Roldan, H. A., Barassi, C. A. and Trucco, R. E. (1985). Increase on free fatty acids during ripening of anchovies ). International Journal of Food Science \& Technology, 20(5), 581-585. (Engraulis anchoita). DOI: https://doi.org/10.1111/j.1365-2621.1985.tb01817.x

Sampels, S. (2015). The effects of processing technologies and preparation on the final quality of fish products. Trends in Food Science \& Technology, 44(2), 131-146. DOI: https://doi.org/10.1016/j. tifs.2015.04.003

Shenouda, S. Y. (1980). Theories of protein denaturation during frozen storage of fish flesh. In Advances in food research (Vol. 26, pp. 275-311). Academic Press. DOI: https://doi.org/10.1016/S00652628(08)60320-1

Shim, K., Yoon, N., Lim, C., Kim, M., Kang, S., Choi, K. and Oh, T. (2017). Relationship between Seasonal Variations in Body and Proximate Compositions of Chub Mackerel Scomber japonicus from the Korean Coast. Turkish Journal of Fisheries and Aquatic Sciences, 17(4), 735-744. DOI: 10.4194/1303-2712-v17_4_09

Sreenath, P.G. and Ravishankar, C.N. (2007). Standardization of process parameters for ready to eat fish products in indigenous polymer coated tin free steel cans (Doctoral dissertation, Cochin University of Science \& Technology). DOI: https://doi.org/10.1111/j.1745-4549.2008.00177.x

Tharaka, T.H.S., Arupala, A.L.Y.H., Jayasinghe, J.M.P. and Abeyrathne, E.D.N.S. (2016). Development of a bread-spread using Catla catla and mature flower buds of Rhizophora apiculata. Sri Lanka Journal of Food and Agriculture, 2(2). DOI: http://doi.org/10.4038/sljfa. v2i2.32

Thiansilakul, Y., Benjakul, S. and Richards, M.P. (2011). The effect of different atmospheric conditions on the changes in myoglobin and colour of refrigerated Eastern little tuna (Euthynnus affinis) muscle. Journal of the Science of Food and Agriculture, 91(6), pp.1103-1110. DOI: https://doi. org/10.1002/jsfa.4290

Uzunlu, S. and Yildirim, I. (2003). Investigation of microbiological quality and microbial changes for different storage temperature and times of raw meat ball. Gida 28, 553-558.

Wang, F., Fu, L., Bao, X. and Wang, Y. (2017). The spoilage microorganisms in seafood with the existed quorum sensing phenomenon. Journal of Food Microbiology, 1(1), 14-19.

www.nara.ac.lk/wp-content/uploads/2017/09/Fisheries-Industry-outlook-2017.pdf $\quad$ www.fsis. usda.gov/wps/portal/fsis/topics/food-safety-education/get-answers/food-safety-fact-sheets/ foodborne-illness-and-disease/clostridium-botulinum/ct_index

Zeng, X., Xia, W., Wang, J., Jiang, Q., Xu, Y., Qiu, Y. and Wang, H. (2014). Technological properties of Lactobacillus plantarum strains isolated from Chinese traditional low salt fermented whole fish. Food Control, 40, 351-358. DOI: https://doi.org/10.1016/j.foodcont.2013.11.048 